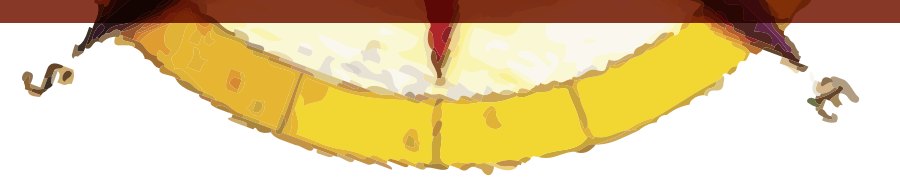

\title{
METODOLOGIAS ATIVAS NA APRENDIZAGEM DA CARTOGRAFIA ESCOLAR
}

\author{
DesenVOLVIMENTO DE RELAÇÕES ESPACIAIS A PARTIR DE SOFTWARE APLICATIVO E
} JOGOS DIGITAIS ${ }^{24}$

Gislaine Batista Munhoz ${ }^{25}$

\section{RESUMEN}

En este artículo se pretende reflexionar sobre la contribución de los juegos digitales basados aprendizaje, puede traer a la geografía. En la Educación Geográfica, y en particular la Escuela de Cartografía de esta nueva perspectiva en la enseñanza y el aprendizaje permite la creación de entornos innovadores y puede proporcionar un aprendizaje más significativo, ya que los profesores y los estudiantes pueden crear simulaciones, el trabajo con situaciones problemáticas, crear espacios imaginarios y/o procesos ficticios cuyo funcionamiento lleven a los estudiantes para tomar decisiones y desarrollar relaciones y habilidades en otros contextos sería más difícil de ser adquridos. La práctica de este enfoque educativo para los estudiantes de primaria, secundaria y superior y la investigación que se ha hecho sobre este tema, ha demostrado la importancia de integrar estos recursos en el aula. Por encima de todo, sin embargo, se da cuenta de la necesidad de considerar con más cuidado y de investigación la cultura juvenil actual, en la que los juegos digitales son parte de la vida cotidiana, así como la formación de profesores de geografía en este contexto.

Palabras clave: juegos, juegos digitales, cartografía de la escuela, relaciones espaciales, aprendizaje basada en juegos digitales.

\section{RESUMO}

Este artigo tem como objetivo fazer uma reflexão sobre a contribuição da aprendizagem baseadas em jogos digitais, pode trazer para a Geografia. Na Educação Geográfica e, em especial, na Cartografia Escolar esta nova perspectiva de ensino e aprendizagem possibilita a criação de ambientes inovadores e podem proporcionar uma aprendizagem mais significativa, na medida em que professores e alunos podem criar simulações, trabalhar com situações-problema, criar espaços imaginários e/ou fictícios em processos cujo desenrolar leva os alunos a tomar decisões e desenvolver

24 Este artigo teve como ponto de partida pesquisa de mestrado defendida na Faculdade de Educação da USP em 2006, com o título A aprendizagem da Geografia Escolar por meio da Informática Educativa.

25 Mestre em Educação pela FEUSP, Especialista EaD, Professora Titular de Geografia e Orientadora de Informática Educativa na Secretaria Municipal de Educação de São Paulo. 
relações e habilidades que em outras contextos seriam mais difíceis de serem adquiridos. A prática desta abordagem educativa com alunos dos ensinos fundamental, médio e superior e de pesquisas que vêm sendo feitas em torno deste tema, tem demonstrado a importância da inserção destes recursos na sala de aula. Acima de tudo, porém, percebe-se a necessidade de considerar de forma mais atenta e investigativa a atual cultura juvenil, na qual os games e/ou jogos digitais são parte do cotidiano, bem como a formação do professor de Geografia neste contexto.

Palavras Chave: games, jogos digitais, cartografia escolar, relações espaciais, aprendizagem baseada em jogos digitais.

\begin{abstract}
This article aims to reflect on the learning-based contribution of digital games, can bring to the geography. In Geographic Education, and in particular the School Mapping this new perspective on teaching and learning enables the creation of innovative environments and can provide a more meaningful learning, as teachers and students can create simulations, working with problem- situations, create imaginary spaces and /or fictitious processes whose functioning leads students to make decisions and develop relationships and skills in other contexts would be more difficult to be acquired. A practice of this educational approach with primary, secondary and college students and researches that have been made on this issue, has demonstrated the importance of integrating these resources in the classroom. Above all, however, realizes the need to consider more carefully and keenly the current youth culture, in which the games are part of everyday life, as well as the training of teachers of geography in this context.
\end{abstract}

Keywords: games, digital games, school cartography, spatial relations, digital game-based learning.

\title{
INTRODUÇÃO
}

As mídias digitais estão aí, não apenas como tendência, mas como uma realidade que se impõe. Atualmente pensar no processo de ensino e aprendizagem deve, primordialmente, levar em conta como cada aluno compreende os conceitos e conteúdos trabalhados e, como esses são aplicados em seu cotidiano, por meio do acesso a estas novas tecnologias, ou como estas podem influenciar nesta aquisição.

Trazer esta realidade para a aula não pode ser feito apenas, para torná-la agradável, criativa. Deve ser uma forma enriquecedora de tornar a aprendizagem significativa, na medida em que pode tornar mais claro, conceitos e conteúdos, às vezes, tão complexos para o aluno.

Inúmeros aplicativos, existentes em diferentes suportes (computadores, notebooks, tablets, netbooks, celulares) têm mecanismos de interação diferentes, mas todos eles têm em comum o interesse dos nativos digitais em manuseá-los e, por este motivo, podem tornar-se um ponto de partida para proposição de diversificadas situações de aprendizagem. Neste contexto, estão plenamente inseridos os jogos digitais: as atividades lúdicas de entretenimento mais utilizadas pelas crianças quando estão em espaços não-formais. 
Os games não são mais apenas um produto que atende certo nicho de mercado, mas um elemento cotidiano para boa parte das pessoas. Videogames estão presentes cada vez em maior número nos domicílios brasileiros: isso sem falar na incrível disseminação dos aparelhos celulares e outros dispositivos móveis no país. A geração de gamers já constitui um grupo muito grande, e não estamos prestando a devida atenção à revolução causada por esse fenômeno. (Mattar 2009, p .XV)

Os jogos tem grande potencial como recurso para a aprendizagem, pois auxiliam na construção cognitiva do aluno, estimulam habilidades importantes para a construção do conhecimento e para a vida: observar, analisar, conjecturar e verificar, compondo o raciocínio lógico, como nos esclarece novamente Mattar (2009):

Por meio dos videogames as crianças aprendem, por exemplo, a brincar com identidades, assumindo e construindo diferentes personalidades virtuais. Em muitos casos, essas personalidades envolvem a identidade de solucionador de problemas, mediante a qual a criança aprende a lidar com erros de uma forma mais dinâmica e interativa do que ocorre, na escola. (p.31)

O autor enfatiza ainda, que o jogo estimula a criatividade, a troca de papeis sociais, à interação, a convivência em situações onde é necessário exercitar a alteridade:

Jogos podem envolver diversos fatores positivos: cognitivos, culturais, sociais, afetivos etc. Jogando as crianças aprendem, por exemplo, a negociar em um universo de regras e a postergar o prazer imediato. (p. XVI)

Nos games, os jovens encontrariam espaços para resignificação, catarse e liberação do estresse diário. Espaços para elaboração de conflitos, medos e angustias. (p. XIX)

A aprendizagem baseada em jogos digitais é temática ainda recente, mas vem se consolidando nos últimos tempos. Foi tratada por Prensk (2001) e, no Brasil, por Mattar (2009) e Tori (2010) cujas reflexões nos ajudam a ter um outro olhar, não somente sobre o processo de ensino e aprendizagem, mas também sobre a forma como os jovens se relacionam com esta cultura no mundo atual. É uma discussão que ainda está florescendo.

A intenção deste artigo não é colocar por terra questões, já abordadas por inúmeros autores com muita propriedade, e sim agregar a elas outras perspectivas que possam favorecer o ato de ensinar. Da mesma forma, não é nosso objetivo colocar esses recursos como panaceia, mas indagar a respeito da contribuição que estas reflexões em torno dos jogos digitais e/ou games e seu poder de entreter pode proporcionar à nossa maneira de ensinar e aprender.

$\mathrm{Na}$ Educação Geográfica e, em especial, na Cartografia Escolar esta perspectiva de ensino e aprendizagem possibilita a criação de ambientes inovadores e podem proporcionar uma aprendizagem mais significativa, em que professores e alunos podem criar simulações, trabalhar com situações-problema, criar espaços imaginários e/ou fictícios em processos cujo desenrolar leva os alunos a tomar decisões. Experiências que tornam conceitos abstratos e, muitas vezes, sem significado para o aluno, concretos e mais próximos do real. A prática desta abordagem educativa com alunos dos ensinos fundamental, médio e superior e de pesquisas que vem sendo feitas em torno destes tema, tem demonstrado a importância da inserção destes recursos na sala de aula. Acima de tudo, porém, percebe-se a necessidade de considerar de forma mais atenta e investigativa a atual cultura juvenil, bem como a formação do professor de geografia. Neste sentido, proponho aqui:

1. Discutir a aplicabilidade no processo de aprendizagem de jogos digitais e/ou softwares de entretenimento considerados a priori não "educativos"; 
2. Analisar a contribuição destes recursos no desenvolvimento das relações espaciais e no estímulo do agir e pensar com lógica;

3. Propor uma reflexão sobre as novas possibilidades metodológicas para os professores;

4. Uma contribuição para a investigação de novas propostas educativas.

Antes, contudo, é importante esclarecer alguns termos e como serão utilizados neste artigo. Apesar de abordar essencialmente os jogos digitais ou games, mostrarei também a aplicabilidade de um software aplicativo, que são aqueles destinados a tarefas especificas, que denomino de sofware de entretenimento, como exemplo, apresentaremos a utilização do software Block Cad criado por Ander Isaksson, um entusiasta dos jogos e brinquedos como o Lego.

Os termos jogos digitais ou games são tratados como sinônimos e se referem a softwares destinados a entreter e divertir.

Um jogo é um objeto que se assemelha a muitos outros, mas possui as suas especificidades: sendo assim, tem a sua própria metodologia de desenvolvimento. Ele se assemelha a um website, pelo fato de possuir uma interface digital e visual, mas um website não tem elementos fundamentais para o sucesso de um vídeo game, como regras e estratégias de jogos; é similar a um filme, pois em muitos casos apresenta cenário, personagens e roteiro, mas até que se prove o contrário, o cinema é um meio cuja estrutura (quadro a quadro) é linear e cuja interação é pouco participativa, no que diz respeito a construção da narrativa por parte do usuário. Desenvolver um jogo, é muitas vezes, parecido com construir um software aplicativo, mas este é uma ferramenta, e o jogo é um produto de entretenimento e cultura (Galisi apud Mattar, 2009, p.XIX)

\section{JOGOS DIGITAIS E SOFTWARE APLICATIVO NA EDUCAÇÃO GEOGRÁFICA}

O uso de novas tecnologias (TICs) na educação é um fato. Elas permitem que tenhamos uma nova forma de pensar sobre o ensino e articular uma nova metodologia que oriente a construção do conhecimento.

Uma prática pedagógica envolvendo o uso das TICs, não pode apenas considerar o uso de aparatos tecnológicos ou recursos informáticos, mas sim pensar em toda uma "arquitetura pedagógica que consiste em "um sistema de premissas teóricas que representa, explica e orienta a forma como se aborda o currículo e que se concretiza nas práticas pedagógicas e nas interações professor-aluno-objeto de estudo/conhecimento". (Behar, 2009, p. 25).

Deste modo, pensar na aplicabilidade dos jogos digitais na educação geográfica está além de simplesmente apresentá-los aos alunos. Deve-se buscar a relação entre o ensino e a aprendizagem significativa, pois, a utilização destes recursos no processo de aprendizagem, permite a articulação de diversos conhecimentos de forma interativa, ou seja, os empregos possíveis incluem desde o potencial de entretenimento, colaboração, interação, dentre outras características próprias de um jogo digital, até a definição de quais conceitos serão trabalhados, passando em seguida ao planejamento, escolha dos objetivos a serem alcançados, metodologia e quais recursos digitais servirão a este intento.

Cada vez mais as TICs e, particularmente, o computador e a internet vem sendo introduzidos na educação, provocando uma verdadeira revolução na nossa concepção de ensino e aprendizagem. 
Segundo Prensky (2001), vivemos um momento em que duas gerações, os "nativos digitais" e os "imigrantes digitais", encontram-se com posturas diferentes frente à esta nova sociedade ou cibersociedade que se impõe. Os primeiros vivenciam a tecnologia de maneira natural como parte de seu universo cotidiano, já os segundos, apesar de incorporar em seus vocabulários a linguagem digital relacionada a esta vivência, apresentam dificuldade e, algumas vezes, receiam em lidar com esta realidade. Precisam de manuais, tutoriais e sentem-se inseguros em ter iniciativa frente ao uso de novos recursos ou ferramentas ligadas ao mundo digital.

Decifrar esta nova geração, entender como pensam e interagem com o mundo a sua volta não é tarefa fácil, não apenas pela complexidade do mundo atual, no qual grande parte das relações interpessoais não são mediadas apenas pelo contato pessoal, mas também por uma infinidade de artefatos eletrônicos, mídias e redes sociais, que diminuem a distâncias, facilitam a vida, inserem outro ritmo de tempo para resolução de tarefas, tornando aparentemente simples algo antes complexo, principalmente para aqueles que dominam este conhecimento.

Lecionando em laboratório de informática, a partir de projetos interdisciplinares é possível perceber que grande parte do sucesso destas aulas se dá pela curiosidade do aluno em aprender ou dominar determinado equipamento eletrônico ou mídia digital, seja ela o computador em si ou um aplicativo, jogo ou software.

O que ocorre é que ainda vemos a característica de diversão do jogo como algo negativo, ou seja, parece que, ao entreter, o jogo perde seu potencial como recurso de aprendizagem. Contudo alguns autores que tratam deste tema em suas publicações numa abordagem diferente daquelas que são feitas normalmente quando se preparam aulas, não descartam a capacidade de entretenimento que o jogo pode proporcionar, mas consideram, a partir daí, que conteúdos podem ser agregados. Nesta nova perspectiva de aprendizagem e partindo de inúmeras pesquisas, Mattar (2009) apresenta o conceito de aprendizado tangencial:

[...] que não é o que você aprende ao ser ensinado, mas o que aprende ao ser exposto a coisas, em um contexto no qual você está envolvido. Há uma separação ainda muito marcante entre games educacionais e games para diversão, principalmente porque vários games educacionais produzidos até agora são muito chatos, quando comparados aos games comerciais.

[...] Sem sermos forçados a prender, e estando envolvidos com os games, temos mais probabilidade de aprender. Portanto, a ideia de aprendizado tangencial considera que uma parte da sua audiência se auto-educará, caso você facilite sua introdução a assuntos que possam lhe interessar, em um contexto que ele considere interessante e envolvente (p. 18)

Mas ao contrário disso, mesmo partindo de uma iniciativa bem intencionada, dependendo de qual e como o jogo é inserido no contexto da aula, muitas vezes "obrigarmos" os alunos a jogarem para "aprender", desprezando assim sua principal característica: a de entreter. Por outro lado, também não conseguimos "educar" e podemos apenas criar uma enorme resistência ao ato de aprender a partir deste recurso.

O resultado da falta de comunicação em sala de aula são alunos indiferentes, desatentos e desmotivados. Para reverter essa situação e começar a realizar seu sonho, não é difícil o educador saber do que necessita: compreender a língua e a cultura da geração gamer e se comunicar nela, tornando as aulas mais divertidas, interativas e desafiadoras. O difícil é saber como fazer para tingir tais metas. Certamente será preciso entender melhor esta nova cultura (Tori, 2010, p. 184). 
O autor segue enfatizando que para "realizar este sonho" o professor precisa entender esta linguagem e/ou estas novas formas de brincar na atualidade para sentir-se seguro ao fazer a transposição didática. Considera um bom caminho para avançar neste processo, frequentar comunidades e sites que abordam o assunto, conhecer jogos educacionais, abrir-se para outros que não tenham este caráter, ler livros e artigos sobre o uso de games na educação, enfim entender de fato o que seria a Cultura dos Jogos Digitais. Ao ter contato com este conhecimento, produzido por pesquisados e jogadores das mais diversas áreas e formações, e ter acesso a estes jogos, o professor poderá com mais tranquilidade e propriedade mediar o processo de aprendizagem, usando softwares de entretenimento e/ou jogos digitais.

Dentre as inúmeras qualidades que os jogos tem, seja digital ou não, duas lhe são próprias: a interação e a colaboração; seja para ganhar, quando o jogo é mais competitivo, para aprender as regras enquanto se joga, para participar como telespectador. Mesmo jogando sozinho, interagindo com a máquina, o jogador buscará colaboração para aprender a jogar, entender as regras, para "passar de fase", para comparar pontuações e pódiuns. Nas redes sociais isso é feito em grande velocidade e, para os imigrantes digitais, o processo parece estranho e efêmero. Mal se apropria de um novo termo ou jogo, ele já se tornou obsoleto. Mesmo que haja certa emergência em agregar uma mídia a nossas aulas, só conseguimos perceber seu potencial e nos apropriar se estiver embutido na mesma uma intenção educativa clara.

A grande maioria dos professores se sente inseguro em usar um conteúdo sem a chancela de "educativo", por isso ainda se ousa pouco na sala de aula. E, mesmo em relação aos recursos digitais de caráter educativo, como os Objetos de Aprendizagem, apesar de vários esforços com repositórios propostos e alimentados por iniciativas de órgãos governamentais, e de diversas universidades nacionais e internacionais, ainda não se nota uma inserção significativa destes recursos no cotidiano das escolas.

Utilizar games ou jogos digitais nas salas de aula, significa repensar outra lógica para a mesma, ou seja, o professor deve permitir que o aluno compartilhe seu conhecimento e, ao mesmo tempo, abrir mão de ser o detentor total da ação de ensinar. É importante ter em mente que a necessidade de propor uma outra organização da aula implica, portanto, em criar ambientes inovadores, como corrobora Moita (2006):

[...] como ambientes virtuais, os games são lugares privilegiados de aprendizagem onde co-habitam a co-construção do conhecimento, a interatividade, a intersubjetividade, autonomia e o alcance de uma consciência critica dos indivíduos, constituindo novos paradigmas epistemológicos da educação, em oposição a perspectiva educacional tradicional ainda vigente em muitas de nossas escolas que, não sintonizadas com a realidade do mundo em que vivemos, não o0ferecem um ensino eficiente e sensível às experiências e dificuldades vividas no cotidianos pelos educandos.

[...] Para tanto, implicam uma nova concepção do que vem a ser o conceito de ambiente de aprendizagem. Ambiente vem de ambi, que significa ao redor, e ente, que remete a ação, qualidade e estado, conduzindo-nos à ideias de lugar ou espaço envolvente. Neste contexto semântico, um ambiente proporciona, ecológica e dinamicamente, relações entre organismos e seu meio circundante na manutenção e evolução da vida (p. 18 e 19)

A mudança de cultura e postura na organização da aula passa também pela concepção do que e como ensinar em Geografia, que não deveria mais ser considerada como uma disciplina de caráter enciclopédico. Essa concepção irá reforçar uma prática que utiliza, por exemplo, o computador 
apenas como um balcão de informações, de onde se extrai ou copia dados, não indo além do uso óbvio dos recursos digitais, como uma enciclopédia eletrônica.

Contudo, o uso inadequado ou imposto de jogos digitais ou de softwares na forma de enciclopédias eletrônicas, podem contribuir ainda mais para ampliar o preconceito que muitos professores têm em relação às mudanças recentes que se impõe às práticas educativas e ainda reforçar a ideia de que um jogo "legal" não pode proporcionar aprendizagem. Alguns jogos, por exemplo, parecem propor o desenvolvimento do raciocínio lógico, mas, ao contrário, são utilizados apenas para o acúmulo de informações, muitas vezes, sem significado. Ou ainda, pesquisas que se transformam em trabalhos impressos, nos quais há inúmeras citações de sites, cujos conteúdos jamais foram acessados ou de fato, lidos.

Estas apropriações inadequadas prejudicam a ideia de como estes recursos podem ser melhor aproveitados, muitas vezes, ao contrário do que se propõe e devido ao mau uso, não contribuem em nada para a aprendizagem e, por conseguinte, vão paulatinamente minando a autonomia do aluno frente ao computador, seus recursos e a aprendizagem que ele pode ajudar a consolidar a partir desta interação.

Podemos observar isto no texto de Borges e Borges (2005), no qual destacamos o que dizem a respeito de como os jogos digitais que, se bem propostos e analisados, podem contribuir para o desenvolvimento do raciocínio lógico e, dessa forma, proporcionar o desenvolvimento de algumas habilidades classificadas da seguinte maneira:

- Ao acaso: seria o que informalmente chamamos de "chute", não foi um conhecimento anterior, ou procedimento lógico que resultou na resposta correta;

- Tentativa e erro: procedimentos aleatórios, que não deram certo são isolados e são tentados outros até que se chegue a um resultado final. Não se levantam hipóteses;

- Ensaio e erro: Há uma hipótese, que é testada, visando uma solução. É realizado um procedimentos com intencionalidade;

- Dedução: analisam-se tentativas já adotadas e constrói-se uma nova estratégia para aí sim chegar a um resultado satisfatório, o erro é utilizado como instrumento de análise.

Corroborando com a ideia de que softwares e jogos digitais podem desenvolver as habilidades descritas acima, os autores alertam sobre a importância do papel do professor enquanto mediador e enfatizam a seguinte questão:

Não havendo por parte do professor uma mediação adequada, a criança corre o risco de ficar limitada apenas nos dois primeiros itens em suas respostas, quando o desejável é que as atividades propiciem estimulações para o desenvolvimento de respostas a situações-problema nos planos do Ensaio e Erro e da Dedução [...] O desenvolvimento exagerado dessas atitudes ocasiona um obstáculo epistemológico ao desenvolvimento do raciocínio por hipóteses, que não são binárias, onde o próprio indivíduo deve fazer suas inferências (Borges e Borges, 2005, p. 8).

Hoje já é possível ter acesso a pesquisas e comunidades que investigam o potencial educativo de games na educação. Procuramos tratar até aqui do potencial dos jogos digitais e softwares de entre- 
tenimento. Alguns autores, nos últimos anos, têm se dedicado a esta temática, trazendo enriquecedoras reflexões às mais diversas áreas do ensino e grande contribuição à aprendizagem. É uma área em grande expansão não só comercial, mas também acadêmica, com abordagens inovadoras e diferenciadas. Meu objetivo é trazer alguns elementos deste discurso para esta reflexão. A partir deste ponto, mostraremos alguns exemplos de nossa prática como professora de geografia e informática educativa, que podem dar mas clareza as afirmações feitas acima:

Iniciaremos por um uma breve apresentação de dois jogos digitais. O primeiro, já bastante antigo, é um jogo que serve de apoio às aulas e tem grande aceitação por parte dos alunos dos primeiros anos no ensino fundamental I, é conhecido como Jogo do ZeeK. O segundo tem características didático-pedagógicas, mais facilmente reconhecidas pelos professores, tem como título "De lá pra cá, de cá pra lá". E por último, apresento o software de entretenimento Block Cad, um aplicativo analisado em minha dissertação de mestrado, com o qual foi possível trabalhar com as relações espaciais em Geografia Em seguida, apresentarei um quadro-síntese, resultado da mesma pesquisa, no qual demonstro como cada um destes recursos, bem como o software Paint - que não exploramos neste artigo - contribuiu ou pode contribuir para o desenvolvimento de conceitos e habilidades imprescindíveis à Cartografia Escolar, bem como demonstrar que, a partir de uma apropriação docente consciente, determinados jogos digitais e softwares de entretenimento podem contribuir para o desenvolvimento de relações espaciais e auxiliar na aprendizagem de conceitos balizares para a Educação Geográfica.

Importante frisar que as experiências aqui relatadas, apesar de mostrarem intenções claramente didáticas, os jogos foram apresentados aos alunos para que conhecessem e explorassem as possibilidades de divertimento e entretenimento de cada um. Foi amplamente estimulando a troca de ideias e o compartilhamento de resultados.

\section{SOFTWARES DE ENTRETENIMENTO E JOGOS DIGITAIS}

\section{Zeek}

Este jogo é bem antigo, foi criado em 1995, por Paul H. Smith e distribuído pela empresa Sidewalk Software. Esta baseado no estilo Sokoban, que consiste em empurrar caixas ou objetos a um lugar determinado dentro de um labirinto, somente uma caixa pode ser empurrada por vez. É relativamente simples, mas bem atrativo, sendo possível começar a trabalhar com estratégia com os primeiros anos no ensino fundamental I. Faz enorme sucesso com as crianças de 6 a 9 anos. Para vencer as fases é necessário criar estratégias para empurrar os blocos e vencer os obstáculos que estão na trajetória do avatar. Para este intento utiliza-se as setas para cima, para baixo, esquerda, direita do teclado. 


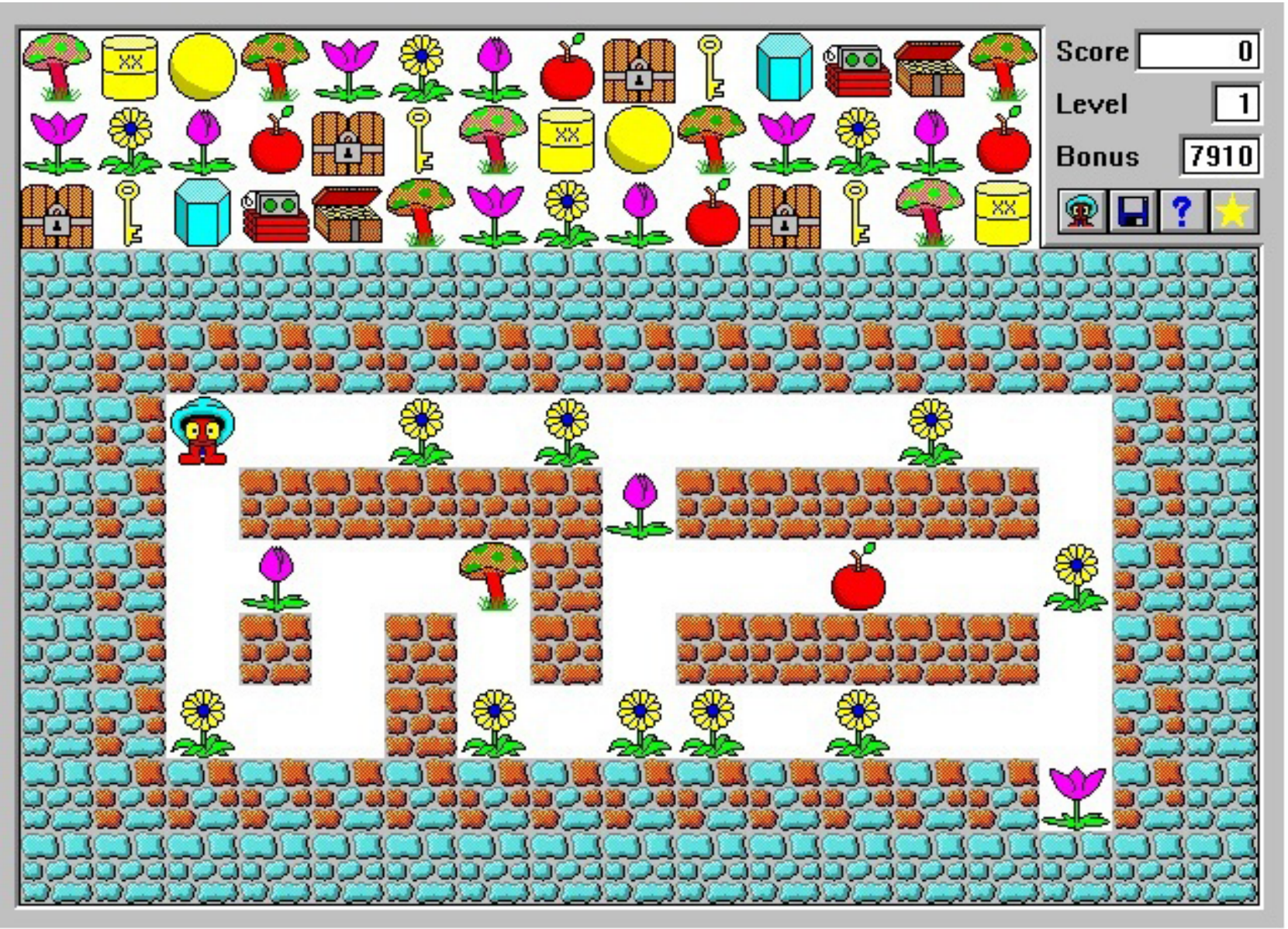

Figura 1. Tela inicial (primeira fase).

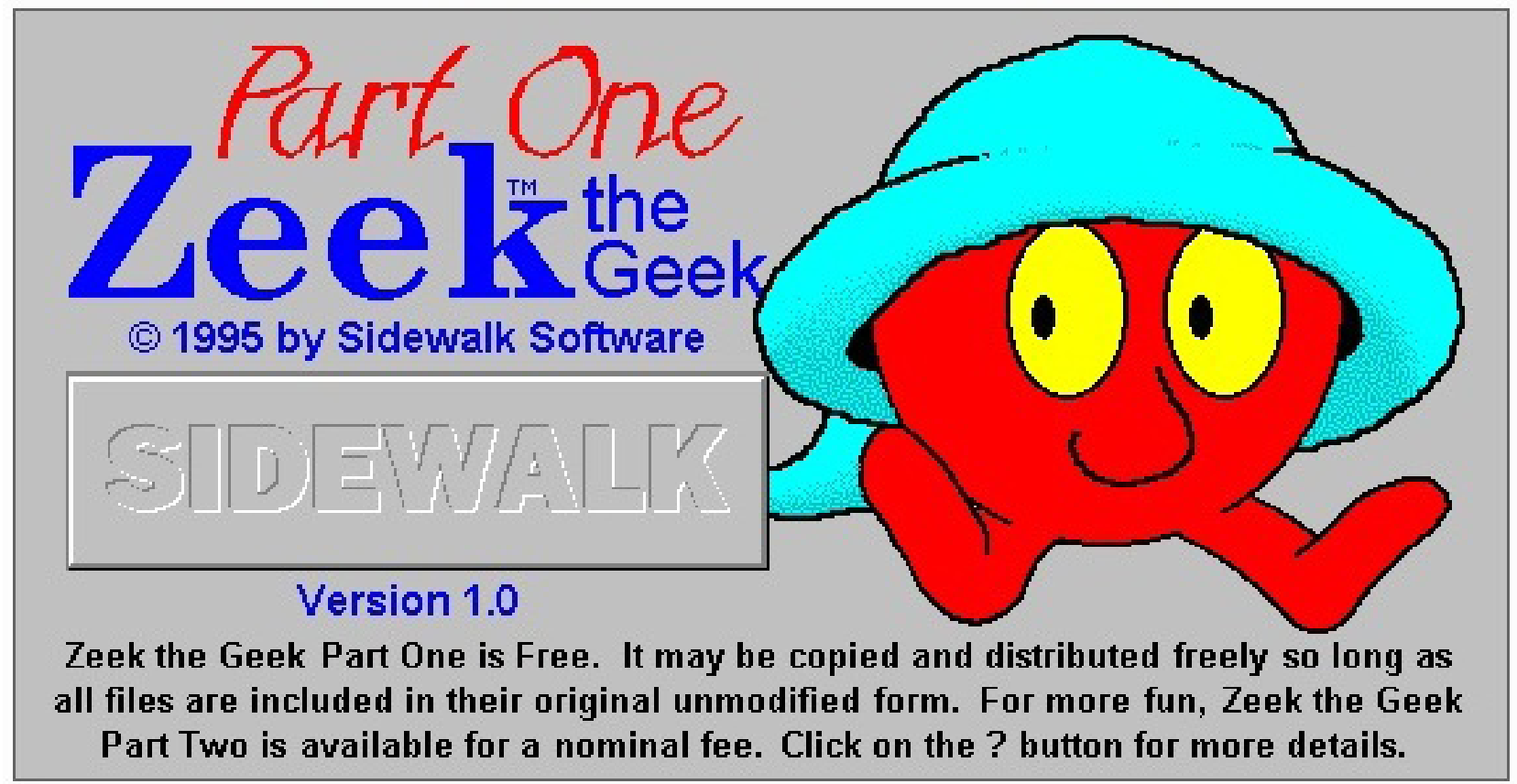

Figura 2. Página de abertura e avatar do jogo. 


\section{De lá prá cá, de cá pra lá}

Ao contrário dos dois outros recursos apresentados aqui este é um jogo distribuído para fins claramente educacionais e consiste em localizar-se utilizando um conjunto de referências espaciais. $\mathrm{O}$ destino é estabelecido no início do jogo e o avatar deve ser guiado deslocando uma seta, acionada pelo mouse que gira o avatar a $45^{\circ}$ ou $90^{\circ}$ graus a esquerda, $45^{\circ}$ ou $90^{\circ}$ a direita e para frente. $\mathrm{O}$ avatar tem uma quantidade de passos pré-determinada para chegar ao destino. Crianças dos primeiros anos do Ensino Fundamental I tem maior dificuldade de brincar, exatamente pela exigência de combinar este conjunto de referencias espaciais, já as crianças dos dois últimos anos do Ensino Fundamental I, com alguma persistência conseguem montar estratégias para vencer as fases. Contudo ao contrário do Jogo Zeek, após descobrirem e desvendarem as regras e desafios do mesmo, não se percebe maior interesse em retornar a jogá-lo.

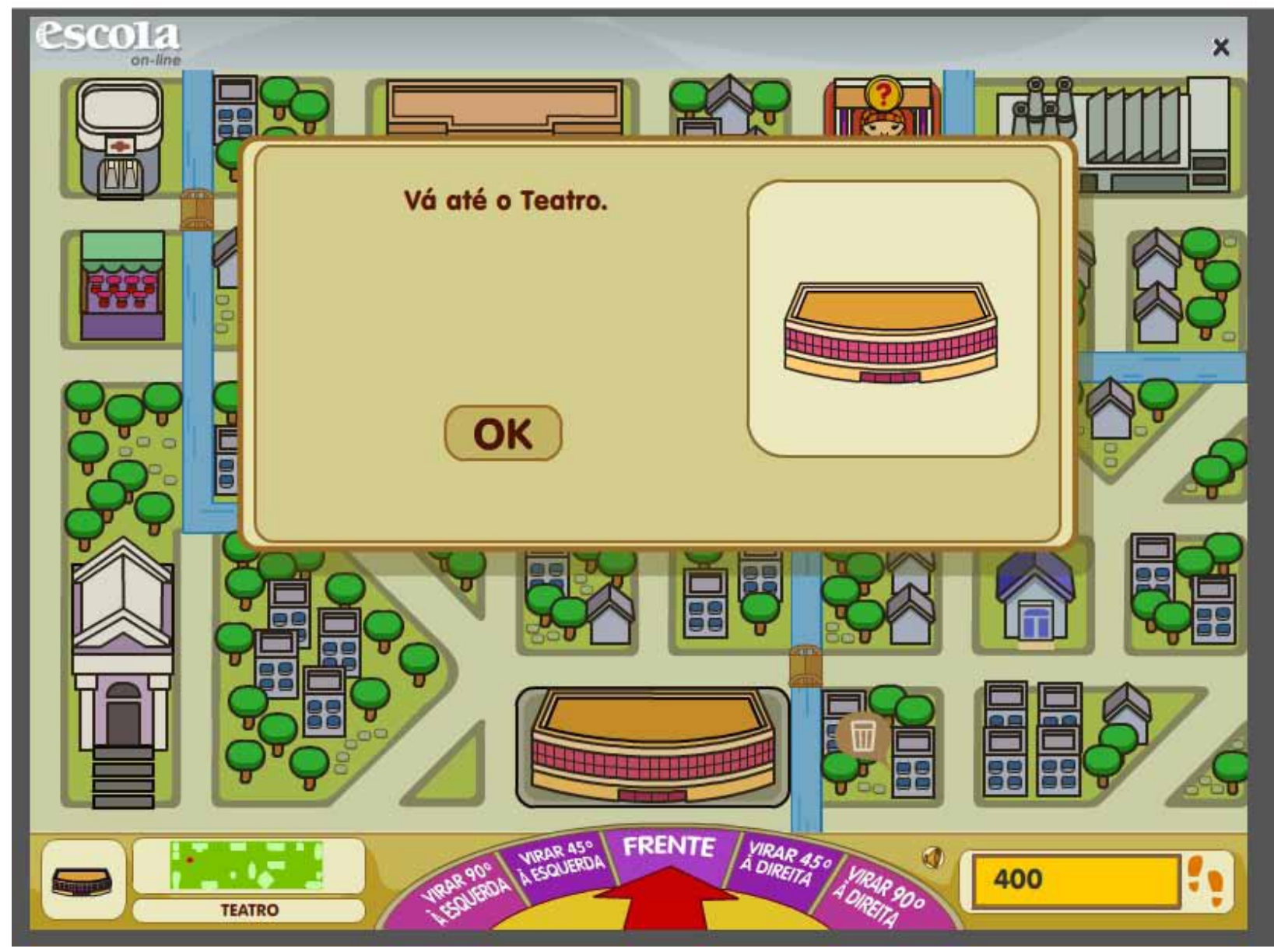

Figura 3. Tela de apresentação do objetivo a ser alcançado pelo jogador. 


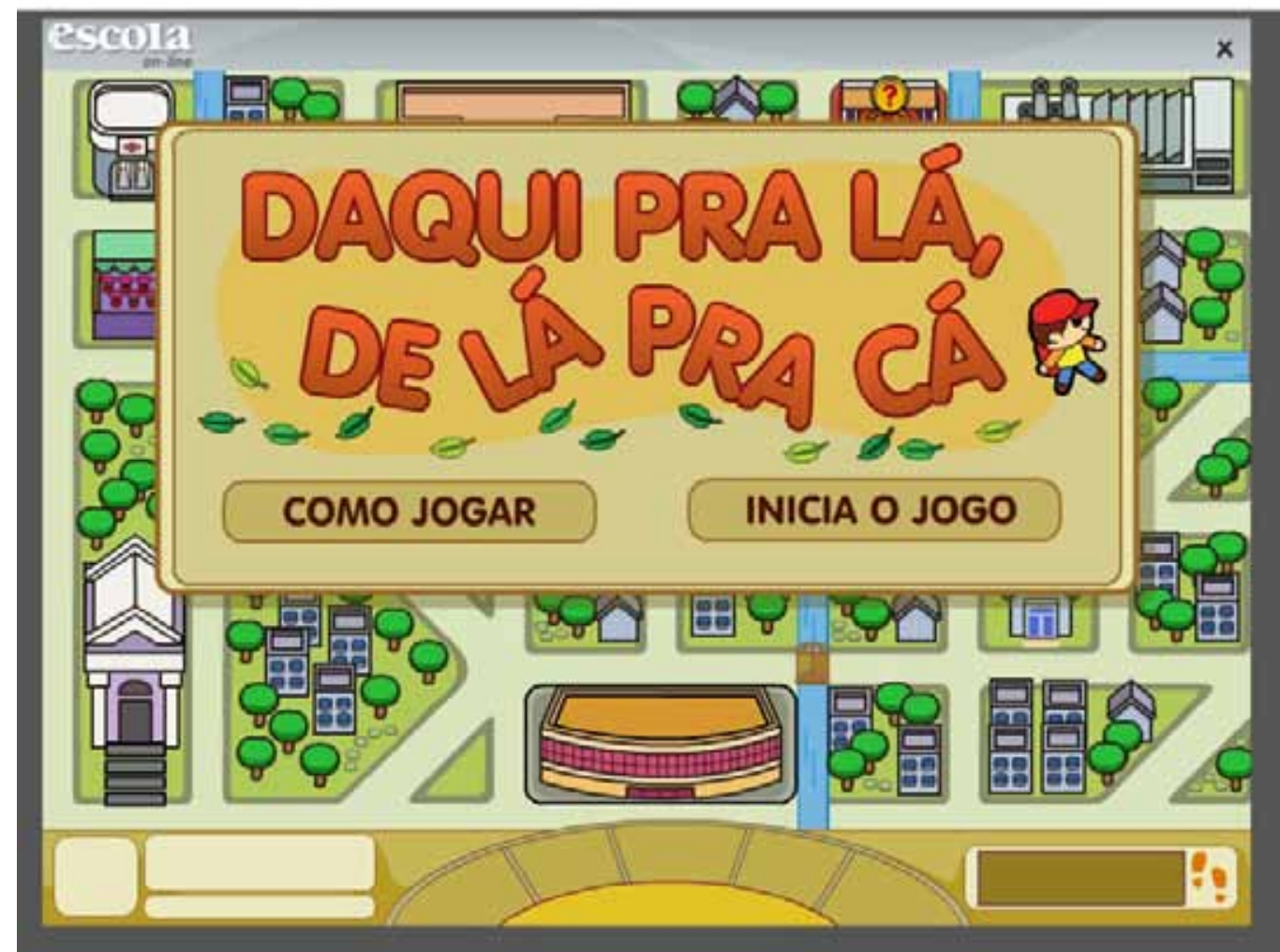

Figura 4. Página de abertura e avatar.

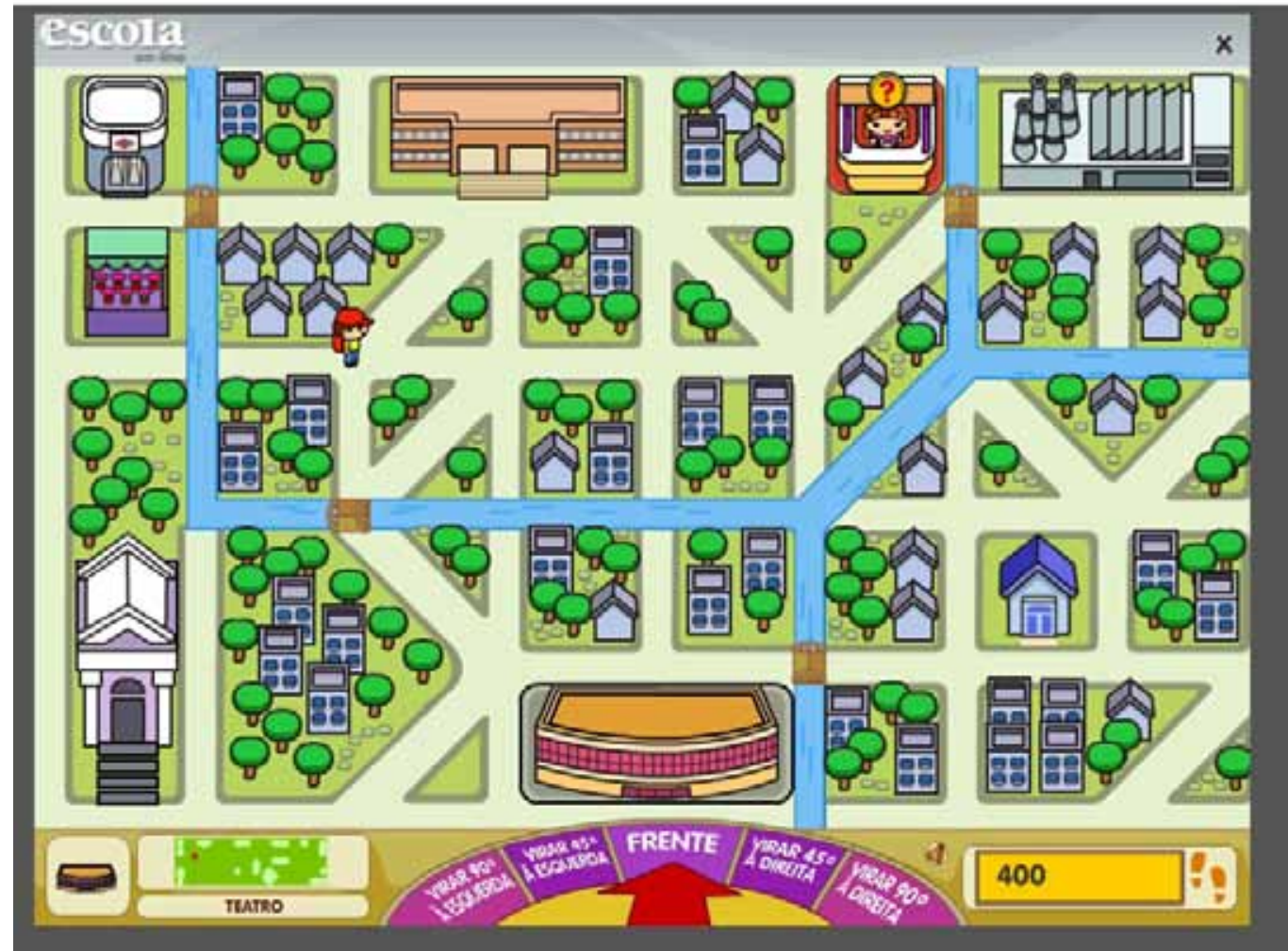

Figura 5. Tela inicial do jogo (primeira fase). 


\section{BlockCad}

O software BlockCad é um softwares Open Source, ou seja, aos usuários mais avançados é permito fazer alterações na configuração do mesmo. Seu criador, Ander Isaksson, mantém um site no qual é possível esclarecer dúvidas e ter acesso a novas peças e criações de todos aqueles que o utilizam, compartilhando estas criações. É um espaço de divulgação do software e de encontro de seus admiradores e usuários.

$\mathrm{Na}$ internet e em revistas que divulgam games, ele é apresentado como o "Lego para computador". É atrativo, instigante, desafiador e com pouquíssimos conhecimentos de informática é possível criar objetos que podem ser construídos e vistos tridimensionalmente, salvar estas peças e "fotografá-las" (copiar e salvar) para que possam ser vistas em formato de imagens.

Para a área de exatas e particularmente para a Geografia, este software abre um amplo leque de possibilidades educativas que vão desde a simples construção de um bloco lógico à criação de cidades inteiras. Há vários campos no software onde é possível fazer cálculos de área, alteração de peças redimensionando tamanhos e cores.

No caso de projeto apresentado logo em seguida cada aluno ficou responsável por construir um elemento que julgasse importante existir em uma cidade. Com todas as peças construídas e disponibilizadas em rede, foram construídas colaborativamente várias modelos de cidades.
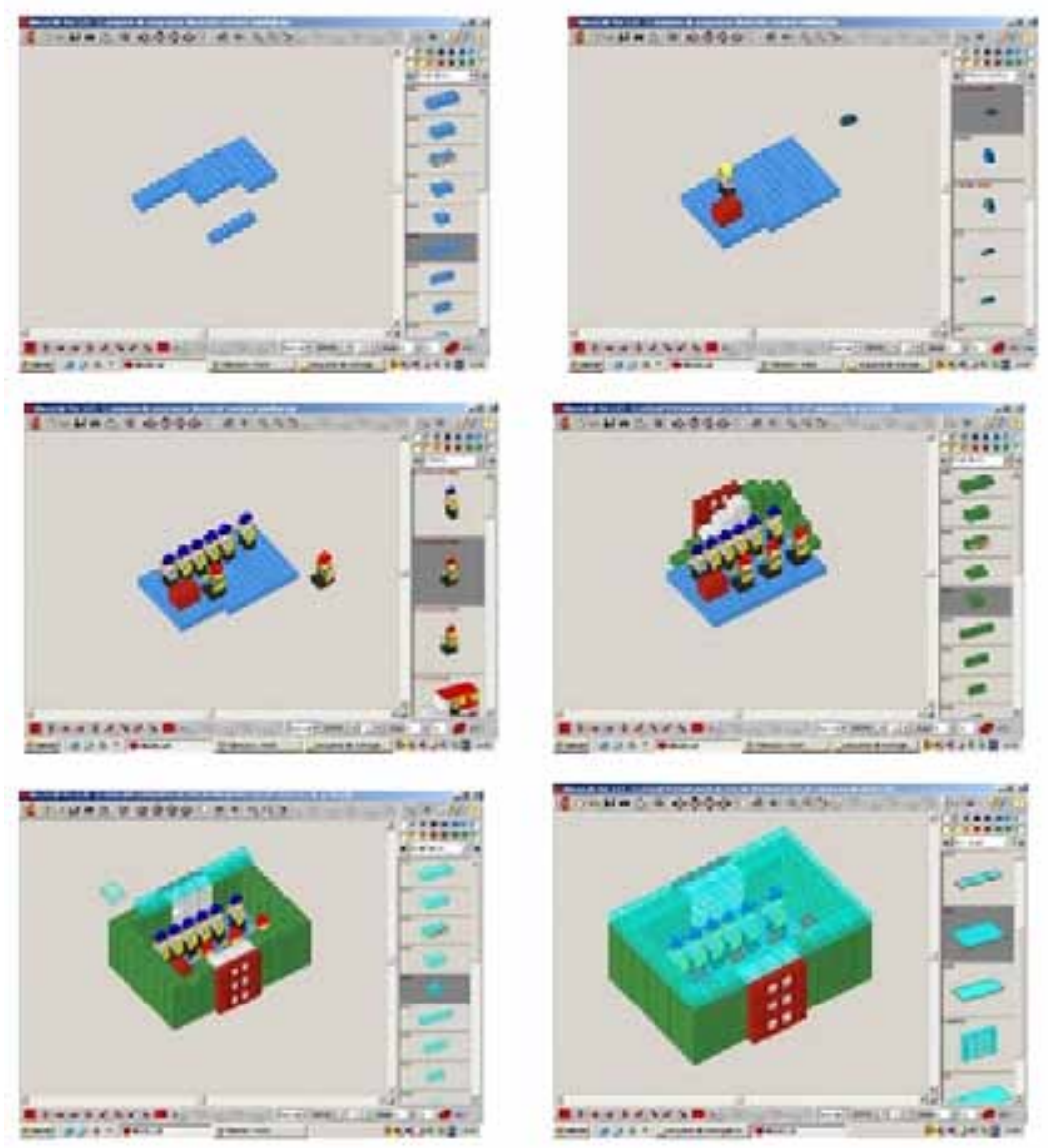

Figura 1.. Esquema de montagem de um elemento no BlockCad. 

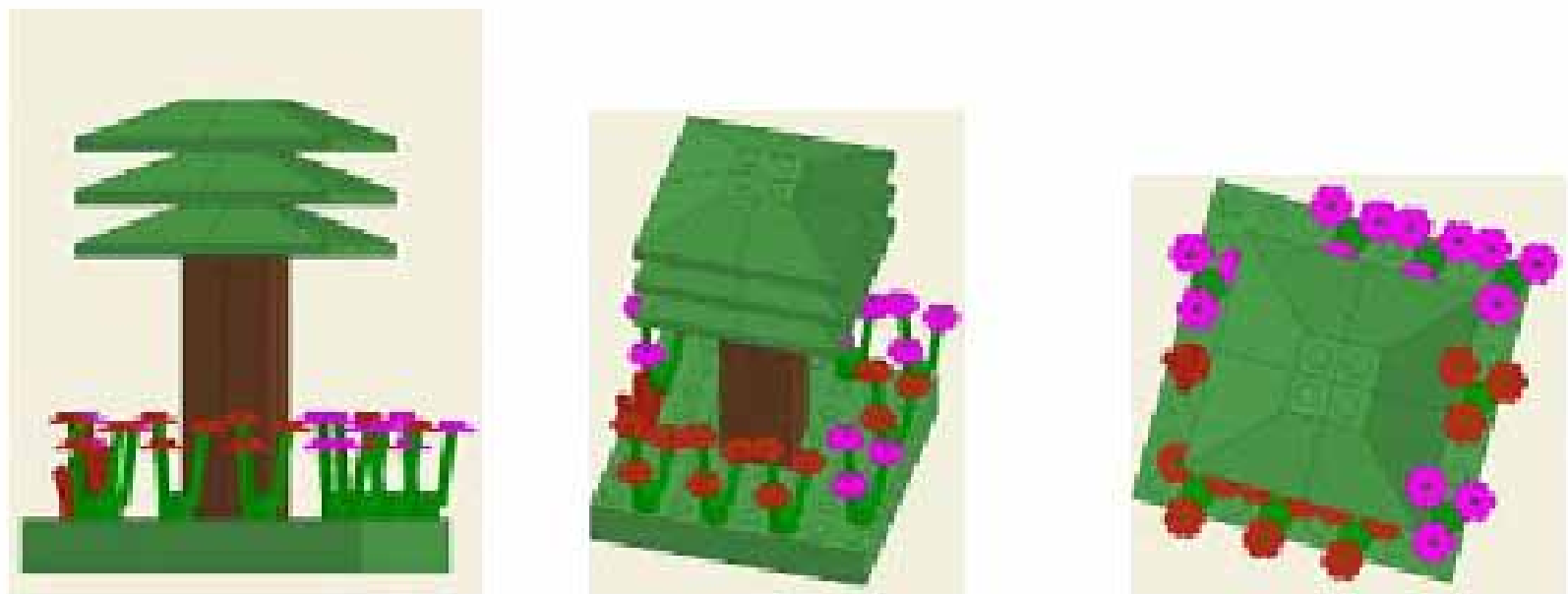

Figura 2. Esquema de montagem de uma árvore na visão frontal, obliqua e vertical.

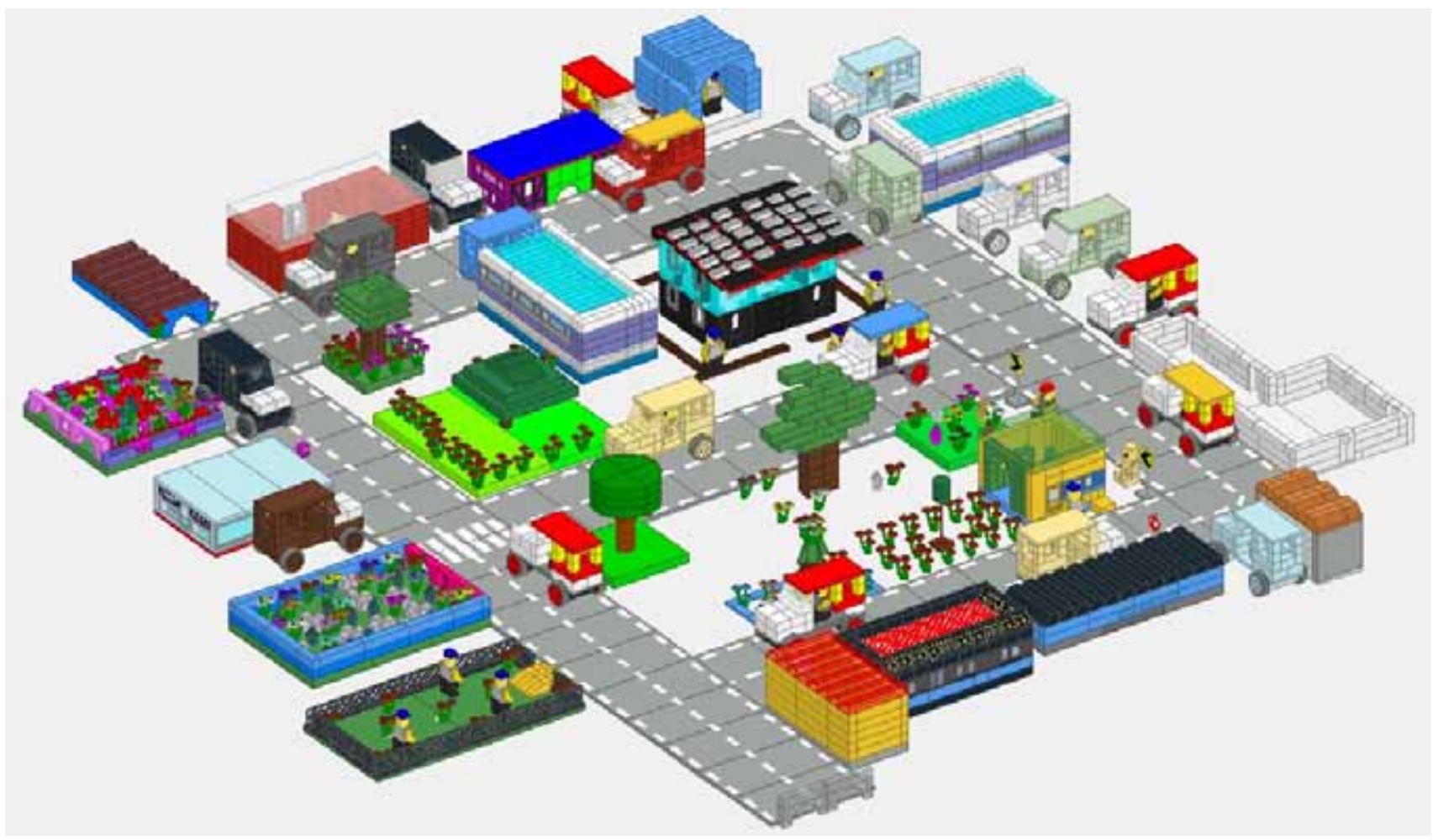

Figura 4. Produto Final: uma cidade construída colaborativamente.

\section{DESENVOLVIMENTO DE RELAÇÕES ESPACIAIS A PARTIR DE SOFTWARES DE ENTRETENIMENTO E JOGOS DIGITAIS}

O processo de construção da noção de espaço é desenvolvido pela criança de forma gradual e progressiva à medida que supera o egocentrismo próprio dos primeiros anos de vida. Na fase egocêntrica, as crianças localizarão objetos no seu espaço, sempre tendo como referencial principal o próprio corpo. Esta etapa será paulatinamente ultrapassada, quando a criança começar a observar 
a localização dos objetos ou elementos em relação a outros objetos ou pessoas, adquirindo assim a noção de descentração ${ }^{26}$. Contudo, há ainda uma distinção entre o que de fato é apreendido a respeito do espaço vivenciado pela criança daquilo que é representado por ela, ou seja, há o espaço perceptivo e o espaço representativo.

O espaço perceptivo é aquele com o qual a criança tem contato primeiramente por meio da manipulação de objetos. Intuitivamente, dá-se na primeira leitura que faz do mundo, de acordo com suas necessidades básicas: engatinhar, falar, andar, etc. e é construído rapidamente. Já o espaço representativo depende de outros fatores, pois se constrói na ausência do objeto, quando a criança consegue, ainda que de forma rudimentar, representá-lo, descrevê-lo. Esta construção, porém, ocorre de forma progressiva passando por duas etapas, ou dois níveis de percepção: o espaço intuitivo e o espaço operatório.

No primeiro, as relações estabelecidas são estáticas e irreversíveis, não há continuidade. Por exemplo, ao representar a rua onde mora, o aluno desenhará a vizinhança de forma descontínua e sem que os objetos representados tenham relação de proximidade, ou seja, não importa a perspectiva sob a qual uma casa possa ser vista, esta sempre será representada da mesma maneira, sem levar em consideração se está ao norte da padaria ou ao sul do mercado. A representação será feita a partir do que foi memorizado pelo aluno.

No segundo nível, o aluno terá condições de operacionalizar relações de proximidade, continuidade, separação, vizinhança, ordem, a fim de representar o espaço topológico. Terá condições de perceber que, dependendo do ponto de vista do observador e da localização em que este se encontra, as representações da rua ou das casas sofrerão mudanças na forma como são desenhadas. Ou seja, ocorrerá à reversibilidade ${ }^{27}$ do pensamento, será necessário outro arranjo mental para operacionalizar esta ação. Ao reconstruir mentalmente esta representação, ela elaborará um novo esquema mental a ser incorporado àquele já existente, e assim sucessivamente até conseguir elaborar relações mais complexas.

Esta distinção entre o espaço perceptivo e o representativo é imprescindível para o aluno, perceber a diferença entre uma foto aérea e uma foto de um aniversário ou uma festa de rua e, consecutivamente, a representação de um mapa. São relações que ao serem estabelecidas permitem a construção dos conceitos de bidimensionalidade, tridimensionalidade, visão oblíquas e visão vertical, por exemplo. Pois, ao perceber que os objetos têm relações entre si de forma recíproca e, apropriando-se desta constatação, o aluno, ao representar o espaço, levará em conta sua percepção e não apenas o que estava memorizado anteriormente.

A reversibilidade é a capacidade de a criança acionar vários dos seus esquemas mentais, conseguindo coordenar diversas noções e relações espaciais. Isto só é possível a partir do momento em que a criança se desvencilhe do egocentrismo infantil (onde tudo é observado e representado a partir de seu ponto de vista) e adquira a descentração. Somente por volta dos nove anos ou mais a criança

26 "Descentrar-se é inverter as próprias relações e construir um sistema de reciprocidades que é qualitativamente novo quanto à ação inicial." Ou ainda "A descentração [...] não é mais que o reverso (ou o aspecto interior, isto é, vinculado ao sujeito) da coordenação operatória." (Piaget apud Battro 1978, p.75).

27 "A reversibilidade verdadeira é a completa descoberta da operação inversa como operação" ou ainda "Chamaremos reversibilidade à capacidade de executar uma mesma ação nos dois sentidos de percurso, mas tendo consciência de que se trata da mesma ação", (Piaget apud Battro 1978, p.215). 
terá condições de perceber a diferença existente entre um objeto representado bidimensionalmente e sua visão tridimensional, desde que tenham sido desenvolvidas estruturas mentais e um conjunto de habilidades condizentes para isso, dentre os quais, a reversibilidades e a descentração.

As primeiras noções adquiridas serão as topológicas, seguidas das projetivas conjuntamente com as euclidianas, esta última, ao contrário, das duas primeiras, constrói-se de forma mais lenta e complexa, simultânea, exigindo da criança a capacidade de descentração.

Este conjunto de noções espaciais, ao qual me refiro, permitirá ao aluno desenvolver habilidades cognitivas para representar o espaço. Por exemplo, ao ser questionada sobre um trajeto, a criança conseguirá descrevê-lo apontando pontos de referências que julgar importantes, localizando-os uns em relação aos outros. Saberá responder se sua casa fica perto ou longe de um local previamente determinado e que faça parte de sua vivência, como a padaria ou a escola. E, para isso, não importa o ponto de partida do trajeto, se sua casa, a escola, ou qualquer ponto outro de referência.

Ressalto que uma forma muito interessante de perceber o pensamento reversível de uma criança é trabalhar com mapas mentais, pois este exercício recupera o espaço vivido pela criança, dando-lhe a possibilidade de se localizar neste espaço, utilizando elementos de sua experiência cotidiana.

Ao explorar as relações topológicas, projetivas e euclidianas, articulando-as com este conhecimento cotidiano e habilidades que o aluno traz consigo, juntamente com os conceitos propostos, o professor estará iniciando o processo de letramento cartográfico. No entanto, é necessário ter clareza quanto ao desenvolvimento cognitivo do aluno e quais noções espaciais devem ser desenvolvidas.

Deste modo, para ampliar a análise sobre as relações espaciais, elaborei três quadros" ${ }^{28}$ " Relações Topológicas", "Relações Projetivas" e "Relações Euclidianas" nos quais sintetizo cada uma das relações espaciais inserindo nesta análise ações cotidianas e ferramentas computacionais que podem contribuir para o desenvolvimento de tais noções. Auxiliando a identificação de qual nível operatório o aluno deve estar apto a utilizar determinada ferramenta.

28 Os quadros foram construídos baseados em dois textos. O primeiro é de Oliveira $A$ noção de espaço e de tempo - O mapa e o gráfico, trata da construção das noções de espaço e tempo pela criança. O segundo é de Patrícia Alejandra Behar, Metodologia de análise de ferramentas computacionais segundo os princípios da lógica operatória trata-se um trabalho inovador que analisa algumas recursos que a mesma denomina de ferramentas computacionais de uso coletivo e individual, utilizando-se da lógica operatória piageteana. Propõe modelos de análise que servem para identificar, tanto na ferramenta como no usuário, as operações lógicas e/ou infralógicas e suas relações com os espaços topológico, projetivo e euclidiano, do qual retiramos alguns exemplos. 


\section{TOPOLÓGICAS ELEMENTARES}

São as primeiras noções adquiridas pela criança ou aluno quando em contato com o espaço vivido. Sendo as mais elementares para a construção e representação do espaço. Essas relações não consideram as convenções utilizadas pelos adultos, nem distâncias ou ângulos. São mais utilizadas no plano perceptivo.

\begin{tabular}{|c|c|c|}
\hline Noções & Ação & $\begin{array}{l}\text { Ação mediante software de entretenimento ou jogo digital } \\
\text { (exemplos) }\end{array}$ \\
\hline $\begin{array}{l}\text { Vizinhança: Os objetos } \\
\text { são percebidos e repre- } \\
\text { sentados próximos uns } \\
\text { dos outros. }\end{array}$ & $\begin{array}{l}\text { Ao se referir a um } \\
\text { objeto a criança irá } \\
\text { localizá-lo sempre } \\
\text { de acordo com o que } \\
\text { está mais próximo: } \\
\text { ao lado de, perto de, } \\
\text { longe de, ali. }\end{array}$ & $\begin{array}{l}\text { Utilizando o editor gráfico Paint, pede-se ao aluno que dese- } \\
\text { nhe uma casa ao lado de uma árvore. Se ele desejar que a casa } \\
\text { e a árvore tenham uma relação de vizinhança, desenhará esses } \\
\text { elementos um ao lado do outro, ao invés de dispersos pela tela. } \\
\text { No software BlockCad*, ao ser solicitado que represente uma } \\
\text { rua com várias casas, elas terão uma relação de vizinhança e } \\
\text { não serão representadas de forma dispersa. }\end{array}$ \\
\hline $\begin{array}{l}\text { Separação: A noção } \\
\text { de separação coexiste } \\
\text { juntamente com a de } \\
\text { vizinhança, quando a } \\
\text { criança percebe que mes- } \\
\text { mo próximos, os objetos } \\
\text { são separados entre si, } \\
\text { ocupando um espaço } \\
\text { próprio. Esta noção au- } \\
\text { menta com a capacidade } \\
\text { de análise e com a idade. }\end{array}$ & $\begin{array}{l}\text { Ao se referir a um } \\
\text { objeto irá apontá-lo } \\
\text { localizando-o entre } \\
\text { objetos próximos: } \\
\text { está entre, no meio } \\
\text { de, abaixo de, em } \\
\text { cima de. }\end{array}$ & $\begin{array}{l}\text { Ao ativar a função recorte do editor gráfico Paint, recortando } \\
\text { uma parte de uma figura ou desenho e colando-a em outro } \\
\text { espaço da tela. Separando este fragmento do todo.** } \\
\text { Ao perceber, no software BlockCad, que uma peça escolhida não } \\
\text { foi bem encaixada, esta é selecionada e a tecla delete acionada. } \\
\text { Assim, o aluno excluirá a peça julgada defeituosa ou mal en- } \\
\text { caixada na montagem. }\end{array}$ \\
\hline $\begin{array}{l}\text { Ordem ou sucessão: } \\
\text { Quando a criança per- } \\
\text { cebe que, apesar de vizi- } \\
\text { nhos e separados, os ob- } \\
\text { jetos têm uma ordem e } \\
\text { sucessão de localização. }\end{array}$ & $\begin{array}{l}\text { Ao se referir a um } \\
\text { objeto, localiza-o de } \\
\text { acordo com outro } \\
\text { que está antes ou de- } \\
\text { pois dele: está depois } \\
\text { de, está antes de, está } \\
\text { logo após. }\end{array}$ & $\begin{array}{l}\text { Ao trabalhar com ferramentas computacionais é necessária } \\
\text { uma ordem de execução, ou seja, a maioria dos comandos } \\
\text { necessita de uma operação encadeada, como por exemplo, o } \\
\text { comando copiar/colar presente em muitos softwares exige que } \\
\text { primeiro seja selecionado o objeto, depois copiado, para que } \\
\text { enfim seja colado em outro contexto. Sem seguir esta ordem } \\
\text { ou sucessão de ações não é possível concretizar a operação*. } \\
\text { No Jogo Zeek, para caminhar pelo labirinto e vencer os obstá- } \\
\text { culos, é necessário perceber primeiramente quais objetos po- } \\
\text { dem engolir o avatar ou podem ajudá-lo, ou qual será necessá- } \\
\text { rio para empurrar uma caixa. É a partir desta observação criar } \\
\text { uma estratégia que envolva uma ordem de acontecimentos. }\end{array}$ \\
\hline
\end{tabular}




\begin{tabular}{|c|c|c|}
\hline $\begin{array}{l}\text { Envolvimento e fe- } \\
\text { chamento: Quando a } \\
\text { criança percebe que um } \\
\text { objeto está interligado } \\
\text { ou dentro de outro, que } \\
\text { há relação, envolvimen- } \\
\text { to entre eles. Esta per- } \\
\text { cepção pode ocorrer em } \\
\text { uma ou mais dimensões, } \\
\text { envolvendo mais de um } \\
\text { objeto. }\end{array}$ & $\begin{array}{l}\text { Ao se referir a um } \\
\text { objeto, este será lo- } \\
\text { calizá-lo em relação } \\
\text { ao seu envolvimento } \\
\text { com outro, ou se está } \\
\text { dentro ou fora dele: } \\
\text { dentro de, fora de, } \\
\text { junto de, entre, etc. }\end{array}$ & $\begin{array}{l}\text { No software BlockCad para montar um carro ou uma casa, por } \\
\text { exemplo, é necessário escolher as peças que, encaixadas entre } \\
\text { si, possam representar este elemento. Ao escolher as rodas e } \\
\text { encaixá-las a uma base plana, representando um carro, o alu- } \\
\text { no percebe que este elemento precisa fazer parte de um todo } \\
\text { para ser representado. } \\
\text { A partir de uma experiência no editor gráfico Paint, desenha-se } \\
\text { o que seria o protótipo de um rosto e fora dele boca, orelhas } \\
\text { e nariz. Pede-se para o aluno recortar e colar cada um desses } \\
\text { elementos nos respectivos lugares. Ao colar o nariz no respec- } \\
\text { tivo lugar, perceberá que este faz parte do todo e que há envol- } \\
\text { vimento com os outros elementos.* }\end{array}$ \\
\hline $\begin{array}{l}\text { Continuidade ou contí- } \\
\text { nuo: Quando há a per- } \\
\text { cepção da continuidade } \\
\text { do espaço. Ao ser adqui- } \\
\text { rida esta noção, será pos- } \\
\text { ta em execução todas as } \\
\text { outras. A criança terá a } \\
\text { clara percepção que não } \\
\text { há rupturas no espaço, } \\
\text { sendo ele formado por } \\
\text { um todo. }\end{array}$ & $\begin{array}{l}\text { Neste caso, a criança } \\
\text { ao se referir a um es- } \\
\text { paço, ou trajeto, por } \\
\text { exemplo, irá utilizar } \\
\text { todas as referências } \\
\text { acima, de forma co- } \\
\text { ordenada e clara. }\end{array}$ & $\begin{array}{l}\text { Quando no editor gráfico Paint, cria-se uma paisagem com } \\
\text { elementos interligados e contextualizados.* } \\
\text { No software BlockCad, para construir as paredes de uma casa ou } \\
\text { uma cidade, é necessário que o aluno tenha a clareza da conti- } \\
\text { nuidade para que as paredes representem de fato uma casa. }\end{array}$ \\
\hline
\end{tabular}

* BlockCad é um software livre que permite a construção de vários objetos na visão tridimensional. Sendo conhecido como uma versão para computador do brinquedo Lego (blocos de encaixe de variadas formas e tamanhos).

** Exemplo extraído de Behar, Patrícia Alejandra - Metodologia de análise de ferramentas computacionais segundo os princípios da lógica operatória.

Se, por um lado, as relações topológicas são as mais elementares, servindo de base para a formulação de todas as outras, por outro, tornam-se um obstáculo para uma localização mais exata dos objetos no espaço, pois mesmo sem utilizá-las é possível se fazer entender, ainda que de forma rudimentar. É muito comum encontrar alunos que, assim como alguns adultos, apesar de terem as estruturas mentais preparadas para a compreensão de relações mais complexas, como as projetivas e euclidianas, encontrem dificuldades ao utilizar tais noções recorrendo à utilização apenas às relações topológicas. 


\section{RELAÇÕES PROJETIVAS}

As relações projetivas permitem que os objetos percebidos sejam coordenados entre si. Sendo possível utilizar um referencial móvel, ou seja, a descrição de sua localização muda de acordo com o ponto de vista do observador. À medida que a descentração se desenvolve, este referencial muda e será possível utilizar outros referenciais, numa evolução gradual das relações topológicas elementares.

\begin{tabular}{|c|c|c|}
\hline Noções/fases & Ação & $\begin{array}{l}\text { Ação mediante software de entretenimento ou jogo digital } \\
\text { (exemplos) }\end{array}$ \\
\hline 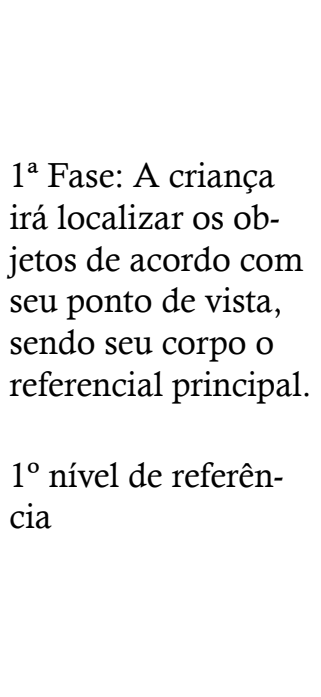 & $\begin{array}{l}\text { A criança, ao apre- } \\
\text { sentar um objeto, só } \\
\text { conseguirá apontá-1o } \\
\text { de acordo com sua } \\
\text { perspectiva. É comum } \\
\text { utilizar o próprio } \\
\text { corpo (braços), para } \\
\text { apoiar sua escolha, o } \\
\text { que ocorre entre } 5 \text { a } 8 \\
\text { anos. }\end{array}$ & $\begin{array}{l}\text { Ao ter contato com um jogo, o aluno conseguirá concebê-lo } \\
\text { numa visão bidimensional. Não será capaz, por exemplo, de } \\
\text { levantar hipóteses relacionadas à ação de um terceiro jogador. } \\
\text { Acompanhará uma luta sempre como telespectador, ainda que } \\
\text { participe do jogo. } \\
\text { Ao ser exigido que coordene o botão direito e esquerdo do mou- } \\
\text { se, o aluno terá dificuldade. } \\
\text { No jogo "De lá pra cá, de cá pra lá" terá dificuldade de posicionar } \\
\text { o avatar utilizando-se das setas que indicam o deslocamento do } \\
\text { mesmo. } \\
\text { Ao construir prédios no software BlockCad (tridimensional), } \\
\text { alguns alunos demoraram a perceber que era necessário construir } \\
\text { as quatro paredes. Muitos se prenderam apenas à fachada. Conce- } \\
\text { bendo e representando assim, apenas sua perspectiva. }\end{array}$ \\
\hline 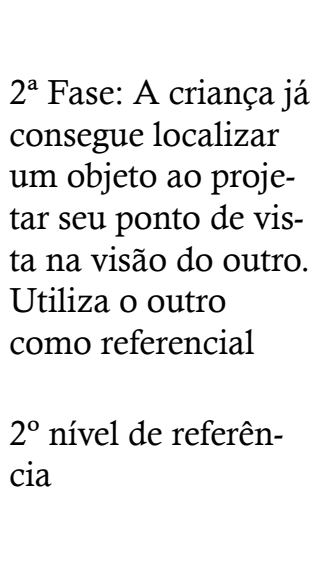 & $\begin{array}{l}\text { Já tem a possibilidade } \\
\text { de se referir aos obje- } \\
\text { tos, de acordo com a } \\
\text { localização de outro } \\
\text { objeto ou individuo: à } \\
\text { direita de, à esquerda } \\
\text { de, à frente de, atrás } \\
\text { de, o que ocorre entre } \\
8 \text { a } 11 \text { anos. }\end{array}$ & $\begin{array}{l}\text { O aluno já consegue coordenar sem dificuldade os botões direito } \\
\text { e esquerdo do mouse. } \\
\text { Nos jogos Zeek e "De lá pra cá, de cá pra lá" já consegue presu- } \\
\text { mir e prepara um ataque, baseando sua ação no deslocamento de } \\
\text { um adversário/obstáculos ou prevê uma situação de perigo, que } \\
\text { poderá impedi-lo ou atrapalhá-lo a chegar ao seu objetivo. } \\
\text { No jogo "De lá pra cá, de cá pra lá" e também no Jogo Zeek, } \\
\text { perceber a tela do jogo com um todo, conseguindo estabelecer } \\
\text { localização do avatar de forma estratégica e qual caminho deverá } \\
\text { percorrer para chegar ao destino estabelecido, ou vencer os obstá- } \\
\text { culos que o impedem de posicionar as caixas corretamente. }\end{array}$ \\
\hline
\end{tabular}




\begin{tabular}{|c|c|c|}
\hline $\begin{array}{l}3^{\text {a }} \text { Fase: A criança } \\
\text { consegue coordenar } \\
\text { vários referenciais } \\
\text { e localiza o objeto } \\
\text { na perspectiva de } \\
\text { outros indivíduos ou } \\
\text { objetos. }\end{array}$ & $\begin{array}{l}\text { Já é possível utilizar } \\
\text { variados pontos de } \\
\text { referências coordena- } \\
\text { dos: está à direita de e } \\
\text { à esquerda de, à frente } \\
\text { e à direita, primeira à } \\
\text { esquerda e segunda à } \\
\text { direita, o que ocorre } \\
\text { entre } 11 \text { a } 12 \text { anos. }\end{array}$ & $\begin{array}{l}\text { Consegue brincar sem dificuldades com jogos em visão tridimen- } \\
\text { sional (3D), prevê o comportamento e defende-se de obstáculos } \\
\text { inesperados, conseguindo coordenar várias ações. Concebendo o } \\
\text { ponto de vista do adversário. } \\
\text { No software BlockCad, preocupa-se com a construção de todos } \\
\text { os lados de uma casa, por exemplo. } \\
\text { No jogo De lá pra cá, de cá pra lá utilizará as setas de indicação } \\
\text { de deslocamento, inferindo quantos graus deverá girar para es- } \\
\text { querda ou para direita para posicionar o avatar para que este ca- } \\
\text { minhe corretamente até o destino estabelecido. } \\
\text { No jogo Zeek conseguirá reelaborar novamente uma estratégia e } \\
\text { testá-la. Levando em conta e inferindo qual dos objetos pode ser } \\
\text { um obstáculo e qual pode ajudá-lo. Terminando o trajeto com su- } \\
\text { cesso e consecutivamente passando de fase. }\end{array}$ \\
\hline
\end{tabular}

À medida que as relações projetivas são adquiridas, é possível notar a gradativa diminuição do egocentrismo infantil. Neste caso, é recomendável ocorrer à substituição de expressões como ao lado de, depois de, por à direita de, à esquerda de. Vencendo-se as três fases de referência, descritas no quadro, a criança já terá a possibilidade de vivenciar a localização geográfica, tendo condições de trabalhar com as direções: norte, sul, leste, oeste numa perspectiva de três dimensões ou plana, ainda tão abstratas à criança quando não se trabalhou as relações projetivas de forma elementar.

As relações euclidianas vão sendo adquiridas juntamente com as projetivas, quando a criança consegue estabelecer noções mais complexas como: conservação de distância, comprimento, superfície, estabelecendo medidas e trabalhando com diversas variáveis para representar o espaço. 


\section{RELAÇÕES EUCLIDIANAS}

As relações euclidianas exigem um alto nível de abstração. Sua aquisição permite utilizar um sistema de referência fixo, estabelecendo relações de distância e comprimento, de forma recíproca, ou seja, é possível elaborar um sistema de coordenadas através de dois eixos, existentes de fato ou concebidos mentalmente. Porém as noções que constituem esta relação são construídas etapa por etapa. Não é por perceber a verticalidade e horizontalidade no próprio corpo que o aluno já terá condições de trabalhar com coordenadas geográficas, por exemplo.

\begin{tabular}{|c|c|c|}
\hline Noções & Ação & $\begin{array}{c}\text { Ação mediante software de entretenimento ou jogo } \\
\text { digital (exemplos) }\end{array}$ \\
\hline $\begin{array}{l}\text { Conservação de Dis- } \\
\text { tancia: } \\
\text { A criança percebe a } \\
\text { distância entre dois } \\
\text { pontos de forma recí- } \\
\text { proca. Conseguindo } \\
\text { definir perto ou longe } \\
\text { em função da distância } \\
\text { percorrida a partir de } \\
\text { um ponto de referência } \\
\text { fixo. }\end{array}$ & $\begin{array}{l}\text { Por exemplo: ao apresentar } \\
\text { ao aluno a página de um guia, } \\
\text { mostrando as ruas pelas quais } \\
\text { costuma passa e destacando } \\
\text { uma destas ruas como referên- } \\
\text { cia principal, ele será capaz de } \\
\text { perceber distâncias relativas } \\
\text { desta rua até sua casa ou até } \\
\text { a escola, podendo determinar } \\
\text { qual destes lugares é mais } \\
\text { distante desta rua principal, } \\
\text { ou seja, a partir de um plano } \\
\text { de referência fixo, o aluno } \\
\text { deve ser capaz de estabelecer } \\
\text { distâncias recíprocas, conside- } \\
\text { rando três variáveis: sua casa, } \\
\text { a escola e a rua principal. Para } \\
\text { fazer esta operação mental- } \\
\text { mente, contudo, desde que se } \\
\text { trate de um trajeto conhecido. }\end{array}$ & $\begin{array}{l}\text { No software BlockCad, para iniciar a construção da } \\
\text { cidade, cada aluno precisou projetar a distribuição das } \\
\text { ruas mentalmente. Desta maneira, foi solicitado que } \\
\text { trabalhasse com um sistema de coordenadas, neste } \\
\text { caso as ruas, que abrigariam, posteriormente, toda a } \\
\text { cidade. } \\
\text { Os que inicialmente não consideraram estas variáveis } \\
\text { tiveram que, mais tarde, adaptar as ruas à distribuição } \\
\text { dos prédios e casas, considerando as distâncias entre } \\
\text { os objetos manipulados. De qualquer forma, havia um } \\
\text { sistema de coordenadas estipuladas pelas ruas ou por } \\
\text { outros objetos que teve de ser considerado, já que o } \\
\text { software não permite que dois corpos ocupem o mes- } \\
\text { mo lugar no espaço. } \\
\text { No mesmo software, para alterar a configuração de } \\
\text { uma peça, era necessário trabalhar com três variáveis } \\
\text { para que as mesmas pudessem ser encaixadas propor- } \\
\text { cionalmente: } \\
\text { X - Comprimento } \\
\text { Y - Largura } \\
\text { Z - Altura }\end{array}$ \\
\hline $\begin{array}{l}\text { Conservação de Com- } \\
\text { primento: } \\
\text { É possível perceber se } \\
\text { esta noção foi adquiri- } \\
\text { da quando independen- } \\
\text { te do deslocamento de } \\
\text { um objeto em relação a } \\
\text { outro do mesmo tama- } \\
\text { nho, a criança continua } \\
\text { considerando que o ob- } \\
\text { jeto deslocado conserva } \\
\text { o mesmo tamanho. } \\
\text { Ainda que dependendo } \\
\text { da perspectiva, possa } \\
\text { parecer o contrário. }\end{array}$ & $\begin{array}{l}\text { Apresentadas duas retas de } \\
\text { igual tamanho e deslocadas } \\
\text { uma delas, o aluno conserva a } \\
\text { ideia de que a reta deslocada } \\
\text { continua com o mesmo com- } \\
\text { primento. } \\
\text { Ou, ao ser proposto que avalie } \\
\text { o comprimento de duas ruas } \\
\text { na página de um guia, o aluno } \\
\text { levará em consideração qual } \\
\text { tem maior comprimento. }\end{array}$ & $\begin{array}{l}\text { No software BlockCad a função "lupa", permite que } \\
\text { um elemento construído seja ampliado ou diminuído } \\
\text { na tela inúmeras vezes. Ao utilizar este comando para } \\
\text { colocar, por exemplo, portas e janelas, aluno percebeu } \\
\text { que o objeto em construção não perdeu suas dimen- } \\
\text { sões reais, mas estava sendo ampliado momentanea- } \\
\text { mente para a inserção de outros detalhes. } \\
\text { Incluídos os "homenzinhos", (que já são trazidos no } \\
\text { software em tamanhos padronizados) ao lado desta } \\
\text { construção era possível perceber que a mesma con- } \\
\text { tinuava com o mesmo tamanho inicial, ou seja, se o } \\
\text { mesmo homenzinho não cabia inicialmente dentro } \\
\text { da casa, não adiantaria aumentá-la usando a função } \\
\text { "lupa", pois ele continuaria não cabendo dentro da } \\
\text { casa. }\end{array}$ \\
\hline
\end{tabular}




\begin{tabular}{|c|c|c|}
\hline $\begin{array}{l}\text { Construção da } \\
\text { Medida ou Compri- } \\
\text { mento: } \\
\text { Consegue estabelecer } \\
\text { medidas de compri- } \\
\text { mento e distância le- } \\
\text { vando em consideração } \\
\text { um sistema de referên- } \\
\text { cia fixo. }\end{array}$ & $\begin{array}{l}\text { A construção da medida es- } \\
\text { pontânea pela criança se dá } \\
\text { em três etapas: } \\
1^{\text {a }} \text { etapa: consegue dividir o } \\
\text { todo em partes, e ver possi- } \\
\text { bilidades de novo encaixe. } \\
\text { Exemplo:cortar vários qua- } \\
\text { drados de papel em variados } \\
\text { tamanhos. } \\
\text { 2a etapa: consegue ordenar } \\
\text { e seriar, numa sequência } \\
\text { espacial, partes de um todo } \\
\text { aparentemente desordenados. } \\
\text { Exemplo: ordenar os quadra- } \\
\text { dos recortados por ordem de } \\
\text { tamanho. } \\
\text { 3a etapa: constitui-se uma uni- } \\
\text { dade de referência, que servirá } \\
\text { de medida para outra organi- } \\
\text { zação dos quadrados cortados. } \\
\text { Exemplo: entre os quadrados } \\
\text { cortados escolha-se um, com o } \\
\text { qual seja possível construir um } \\
\text { barco de papel. } \\
\text { ferência outros quadrados de } \\
\text { papel de mesmo tamanho são } \\
\text { escolhidos. }\end{array}$ & $\begin{array}{l}\text { No software BlockCad esta noção pôde ser trabalhada } \\
\text { quando foi preciso alterar medidas de uma peça para } \\
\text { compor um elemento, aumentando ou diminuindo sua } \\
\text { altura, largura ou comprimento. } \\
\text { Este recurso foi muito utilizado para a construção de } \\
\text { telhados, por exemplo. } \\
\text { No software BlockCad, a construção de medida de } \\
\text { comprimento foi usada durante todo o processo de } \\
\text { construção da cidade, pois, para cada novo elemento } \\
\text { encaixado na cidade, era necessário levar em conta, o } \\
\text { tamanho, deste em relação ao todo. }\end{array}$ \\
\hline
\end{tabular}

Ao analisar a aquisição das noções topológicas projetivas e euclidianas como elementares para a construção das relações espaciais, Piaget afirma que, entre 11 e 12 anos, as crianças já conseguem utilizar as noções adquiridas na escola relacionando-as com aquelas elaboradas por ela mesma.

No caso dos esquemas topográficos, assistimos a uma passagem comparável do natural ao convencional, ou, dizendo melhor, do concreto ao formal, mas, como o desenvolvimento das operações formais torna possível a aquisição de noções escolares relativas aos esquemas cartográficos e aos eixos de coordenadas, as crianças de 11 e 12 anos que interrogamos apresentam um mistura de noções elaboradas individualmente e de noções adquiridas (Piaget \& Inhelder, 1993, p.465).

Sua preocupação estava centrada em como se originava o conhecimento dentro das estruturas mentais do indivíduo e como esta estrutura atuava para a formação dos esquemas de ação, ou seja, agindo sobre e com esses objetos o aluno construirá o que Piaget chamou de "esquemas de ação".

O esquema de uma ação é, por definição, o conjunto estruturado dos caracteres generalizáveis desta ação, isto é, dos que permitem repetir a mesma ação ou aplicá-las a novos conteúdos. Mas o esquema de uma ação não é nem perceptível (percebe-se uma ação particular, mas não seu esquema) nem diretamente introspectível e só toma consciência de suas implicações repetindo a ação e comparando seus resultados sucessivos (Piaget apud Battro, 1978, p.92). 
Por conseguinte, os esquemas de ação são modelos previamente construídos pelo indivíduo para serem utilizados em uma nova ação e dentro de outro contexto, por exemplo, quando a criança leva o dedo à boca para sugá-lo, esta ação será adaptada a uma nova realidade quando a criança precisar colocar um alimento ou um objeto à boca para comê-lo ou manuseá-lo oralmente. Desta maneira, para Piaget, conforme citado em Battro (1978), os esquemas de ação constituem a principal fonte de conceitos.

Com base nestas afirmações, é possível concluir que a interação do aluno com os objetos que estão à sua volta é capaz de lhe proporcionar o conhecimento, pois na relação do aluno com estes objetos se construirá o conhecimento. A formulação de novos e sucessivos esquemas de ação propiciará a formação e consolidação de novos conceitos. Isto posto, resta afirmar que os jogos digitais parecem recursos privilegiados para estas aquisições.

\section{CONSIDERAÇÕES FINAIS}

Diante das reflexões acima suscitadas, um impasse que se coloca é ainda como preparar o professor para utilizar estes novos recursos. Como fazê-lo sentir-se seguro e apto a se apoiar nestas mídias para instaurar uma nova lógica, outra forma de pensar suas aulas, ou seja, mudar o foco do conteúdo não em seu aspecto primordial, mas como ferramenta para construir conceitos estruturantes para a aprendizagem e conseqüente construção do conhecimento.

Uma nova realidade se impõe, na qual os alunos aprendem colaborativamente entre si. O professor, por sua vez, necessitará dimensionar sua aula de forma coletiva com seus alunos, num processo de construção mútua de diferentes conhecimentos. A abordagem da aprendizagem baseada em jogos digitais tem demonstrado esta tendência, que já percebemos com mais clareza em nossas casas, com filhos, sobrinhos e netos, mas que, por algum motivo, receamos que entrem em nossas salas de aula. Talvez por julgarmos a priori não ter os jogos de entretenimento um caráter apropriadamente educativo.

Claro está que é imprescindível levar em conta a questão do consumismo, dos "perigos" da internet, da superexposição a propagandas, etc. Contudo, estes recursos estão à nossa volta e são utilizados por nossos alunos. Agregá-los à nossa rotina de trabalho docente, não significa apenas tornar as aulas mais interessantes, mas também agregar conhecimentos e metodologias de outras áreas do conhecimento e, principalmente, interagir com este novo universo cultural que se impõe e ao qual não estamos imunes.

Talvez estejamos num momento similar àquele em que os quadrinhos (HQs) começaram a adentrar a sala de aula com todos os questionamentos intrínsecos ao uso de um novo recurso: será adequado? Apropriado? Trará resultados? Etc. Hoje o uso dos gibis não parece mais questionável. O momento atual é o da Cultura da Convergência ${ }^{29}$ na Educação, quando o velho e o novo coexistem, sem necessariamente que um seja pior ou melhor que o outro. Ambos são pontos que se encontram e se convergem para outra direção, outro caminho, agregando conhecimentos já estabelecidos aos que se produzem na contemporaneidade.

Ouso dizer que talvez o uso dos games carrega, arraigados em si, um caráter negativo porque a Educação ainda não se apropriou deste recurso de fato, sendo as grandes corporações e indústria 
de entretenimento seus grandes criadores e detentores, com objetivos, muitas vezes, distanciados daqueles propostos pela Educação. É preciso, contudo, avançar além da crítica pela crítica e (re) conhecer o que a (nem tão) nova cultura dos games tem a nos ensinar e proporcionar.

Jogadores, pesquisadores de jogos e professores, têm pontos que nos aproximam, ou seja, queremos uma sociedade com cidadãos plenos de vontades, desejos e que, como tal, estejam capacitados a escolher como se divertir e aprender, utilizando para isso recursos e ferramentas das mais diversas, com as quais possa interagir, colaborar e expandir seus conhecimentos.

\section{BIBLIOGRAFIA}

Asary, A Y.; Moura, J. D. P. "Uso de computadores no Ensino de Geografia". In: Asary, A.Y.; Antonello, I. T.; Tsukamoto, R. Y. (2004) Múltiplas Geografias: Ensino-Pesquisa-Reflexão. Londrina: Edições Humanidades, 161-173.

Alves, S. (2011) Dicionário de tecnologia educacional - Terminologia básica apoiada por micromapas. São Paulo: PerSe.

Almeida, R.D. (org.). (2010) Cartografia escolar. São Paulo: Contexto, 2010.

(org.). (2011) Novos rumos da cartografia escolar - Currículo, linguagem e tecnologia. São Paulo: Contexto.

Battro, A. M. (1978). Dicionário terminológico de Jean Piaget, São Paulo: Pioneira.

Behar, P. A. et al. (2003) "Metodologia de análise de ferramentas computacionais segundo os princípios da lógica operatória”. Educação e Pesquisa. São Paulo, 29 (1).

Behar, P. A. e colaboradores. (2009) Modelos Pedagógicos em Educação a Distância. Porto Alegre: Artmed.

Behar, P. A. (2009) "Arquiteturas Pedagógicas para a Educação a Distância: a construção e validação de um objeto de aprendizagem". RENOTE - Revista Novas Tecnologias na Educação: Porto Alegre, 7 (1).

Borges H. N., Borges, S. M. C. O papel da Informática Educativa no desenvolvimento do raciocínio lógico. Disponível em http://www.multimeios.ufc.br/arquivos/pc/pre-print/O_papel_da_ Informatica.pdf acesso em: 10 jun. de 2005.

Callai, H. C. (org.) (2011). Educação geográfica - Reflexão e prática. Ijuí (RS): Editora Unijuí (coleção Ciências Sociais).

Castellar, S. M. V. (1995). "A construção do conceito de espaço e o ensino de Geografia". Caderno Prudentino de Geografia - Geografia e Ensino - AGB - Seção Prudente (17),94-114.

. (org.) (2005) "Educação Geográfica e as Teorias da Aprendizagem". Caderno Cedes, Campinas, 25 (66). 
Castellar, S. M. V.: Moraes, J. V.; Sacramento, A. C. R. "Jogos e resolução de problemas para o entendimento do espaço geográfico no ensino de geografia". Callai, H. C. (org.). (2011) Educação geográfica. Reflexão e prática. Ijuí (RS): Editora Unijuí. (Coleção Ciências Sociais).

Cavalcanti, L. S. (1998). Geografia, escola e construção de conhecimentos. Campinas: Papirus (Coleção Magistério: Formação e Trabalho Pedagógico).

Conselho Nacional de Pesquisa Dos Estados Unidos. (2007) Como as pessoas aprendem. Cérebro, mente, experiência e escola. Tradução de Carlos David Szlak. São Paulo: Editora Senac.

Isaksson, A. (1998). Block Cad. Suécia.Disponível em http://www.blockcad.net/proglego.htm Acesso em: 03 fev. 2005.

Jenkins, H. (2009). Cultura da Convergência. São Paulo: Aleph.

Moita, M. G. S.C. Games Contexto Cultura e Curricular Juvenil (2006) (Tese de Doutorado), Centro de Educação, Universidade Federal da Paraíba, 2006, João Pessoa. Disponível em http://www. filomenamoita.pro.br/pdf/tese-games.pdf, acesso em: out. 2011.

Mattar, J. (2010). Games em educação - Como os nativos digitais aprendem. São Paulo: Pearson Prentice Hall.

Moran, J. M.; Masseto, M. T.; Behrens, M. A. (2000). Novas tecnologias e mediação pedagógica. Campinas/São Paulo: Papirus.

Moraes, J. V., Sacramento, A. C. R.(2007). Jogos e situações problemas no Ensino de Geografia. Rio de Janeiro: Anais $9^{\circ}$ ENPEG.

Munhoz, G. B. (2006). A aprendizagem da Geografia por meio da Informática Educativa. Dissertação apresentada à Faculdade de Educação da USP. São Paulo.

Munhoz, G. B.; Sacramento, A. C. (2011) "The Learning Objects: A way to teaching geography in basic school". Problems of Education in the 21 $1^{\text {st }}$ Century. Issues in Geographical Education, 27, $100-111$.

Munhoz, G. B.; Castellar, S. M.V.; Sacramento, A. C. R. (2011). "Recursos multimídia na educação geográfica: perspectivas e possibilidades". Ciência geográfica. Bauru XV (1), 114-123. Disponível em: http://www.agbbauru.org.br/publicacoes/ revista/anoXV_1/AGB_dez2011_artigos_versao_internet/AGB_dez2011_16.pdf. Acesso em: 06 dez. 2011.

Oliveira, L. (1986) Estudo metodológico e cognitivo do mapa. Tese de Doutorado apresentada ao Departamento de Geografia, FFLCH/USP, São Paulo.

Oliveira, L, Rio, V. D. (1999) Percepção e representação do espaço geográfico. Percepção ambiental: a experiência brasileira. São Carlos: Editora da UFSCAR.

Piaget, J. (1993) A representação no espaço na criança. Porto Alegre: Artes Médicas. 
Prensky, M. (2001) "Digital natives, Digital immigrants". On the Horizon. United Kingdom, MCB University Press, 9 (5). Disponível em: http://www.marcprensky. com/writing/Prensky\%20-\%20Digital\%20Natives,\%20Digital\%20Immigrants\%20-\%20Part1.pdf, acesso em: 10 set. 2011.

. (2001) "The digital game based learning revolution". Prensky, M. Digital game based learning. McGraw-Hill, s.1. Disponível em http://www.marcprensky.com/writing/prensky\%20-\%20ch1-digital\%20game-based\%20learning.pdf, acesso em: 10 ago. 2011.

Prata, C. L.; Nascimento, A C. A. A. (Orgs). (20007) Objetos de aprendizagem: uma proposta de recurso pedagógico. Brasília: MEC, SEED.

Revista Nova Escola. (sem data). Daqui pra lá, de lá pra cá. Disponível em http://revistaescola. abril.com.br/matematica/pratica-pedagogica/jogo-espaco-forma-428061.shtml, acesso em: 03 fev. 2011.

Silva, E. F. (2011) Nove aulas inovadoras na universidade. Campinas: Papirus Editora (Coleção Magistério: Formação e Trabalho Pedagógico).

Simielli, M. E. R. (1996) Cartografia e Ensino - Proposta e Contraponto de uma Obra Didática, Livre Docência apresentada ao Departamento de Geografia, FFLCH/USP, São Paulo. Tori, R. (2010) Educação sem distância. As tecnologias interativas na redução de distâncias em ensino e aprendizagem. São Paulo: Editora Senac.

Smith, P. H. (1995). Zeek. Sidewalk Software. Disponível em http://pauls-place.awardspace.com/ zeek.html e http://sokoban-jd.blogspot.com/2011/6/zeek-geek.html, acesso em: 09 set. 2011. 